\title{
A new species of Dactylopusioides (Copepoda: Harpacticoida: Thalestridae) infesting a brown alga, Dictyota dichotoma in Japan
}

\author{
Takaki Shimono ${ }^{1}$, Nozomu Iwasaki ${ }^{2} *$ \& Hiroshi Kawai ${ }^{3}$ \\ ${ }^{1}$ Graduate School of Science and Technology, Kobe University, Rokkodai, Nadaku, Kobe 657-8501, Japan \\ ${ }^{2}$ Usa Marine Biological Institute, Kochi University, Usa-cho, Tosa, Kochi 781-1164, Japan \\ ${ }^{3}$ Kobe University Research Center for Inland Seas, Rokkodai, Nadaku, Kobe 657-8501, Japan \\ (*Author for correspondence: Tel.: +88-856-0422, Fax: +88-856-0425, E-mail: iwasakin@cc.kochi-u.ac.jp) \\ Received 3 December 2002; in revised form 16 December 2003; accepted 4 February 2004
}

Key words: Harpacticoida, Dactylopusioides, brown alga infestation, Japan

\begin{abstract}
Dactylopusioides fodiens sp. nov. (Copepoda: Harpacticoida: Thalestridae) is described from the west seaboard of Japan on the Sea of Japan. The species infests a brown alga, Dictyota dichotoma. It lives in galleries that it makes by eating the interior of the thallus.
\end{abstract}

\section{Introduction}

Many species of harpacticoid copepods belong to the Harpacticidae, Tisbidae, Porcellidiidae, Peltidiidae, Tegastidae, Thalestridae and Diosaccidae associate with sea grass and seaweeds (Hicks, 1977). Although most of these live on the surface of fronds of sea grass and seaweeds, six species of thalestrid copepods are known that live in burrows which they make in the thallus and in some species small gall-like swellings are formed which project from the frond surface. Amenophia orientalis Ho \& Hong, 1988 and Parathalestris infestus Ho \& Hong, 1988 infest a brown alga, Undaria pinnatifida making pinholes (Ho \& Hong, 1988). Dactylopusioides macrolabris (Claus, 1866) is found in small galleries between cell walls (and associated cuticles) of cortical cells of a brown alga, Dictyota dichotoma (Green, 1958). Diarthrodes feldmanni Bocquet, 1953 and Diarthrodes cystoecus Fahrenbach, 1954 attack several species of Rhodophyceae and the later forms galls on the surface of fronds Bocquet, 1953; Fahrenbach, 1954, 1962. Thalestris rhodymeniae Brady, 1894 associates with a red alga, Rhodymenia palmata (=Palmaria pal- mata) producing galls (Brady, 1894; Harding, 1954).

The present paper describes a new species of Dactylopusioides from the west seaboard of Japan on the Sea of Japan. The species infests $D$. dichotoma, making the galleries by eating the interior of the thallus in the same manner as D. macrolabris.

\section{Materials and methods}

Copepods infesting the brown alga, Dictyota dichotoma were collected in the subtidal zones at Imagoura, Hyogo Prefecture lying on the coast of the Sea of Japan on 11 April 1999. Copepods were cultured with small pieces of $D$. dichotoma in the PESI culture medium (Tatewaki, 1966) at $20{ }^{\circ} \mathrm{C}$ with alternate light $(16 \mathrm{~h})$ and dark $(8 \mathrm{~h})$ periods.

Specimens were fixed in $2 \%$ formaldehyde seawater. Dissection was carried out under the binocular microscopy SMZ-U (Nikon, Tokyo, Japan). Dissected specimens were mounted on slides in polyvinyl lactophenol. All figures were 
prepared by tracing the photomicrographs taken by the microscope digital camera DP-11 (Olympus, Tokyo, Japan) attached on the Nomarski light microscopy BX-50 (Olympus, Tokyo, Japan).

The nomenclature and terminology used throughout are adopted from Huys et al. (1996). The following abbreviations are used throughout this paper: P1-P6, the six pairs of pereiopods.

\section{Description}

Order Harpacticoida Sars, 1903

Family Thalestridae Sars, 1905 sensu Lang, 1948

Genus Dactylopusioides Brian, 1928

Dactylopusioides fodiens sp. nov. (Figs. 1-3)

\section{Type material}

Holotype. Adult female (total body length $0.72 \mathrm{~mm}$ ) deposited in the British Museum, Natural History, under registration number NHM 2003.1061.

Paratypes. 10 females and 2 males deposited in the British Museum, Natural History (registration number NHM 2003.1062-1073). 10 females and 2 males deposited in the National Science Museum, Tokyo, Japan (NSMT-Cr 15711-15722).

Type material from brown algae, Dictyota dichotoma in Imagoura, Hyogo Prefecture $\left(35^{\circ} 40^{\prime} \mathrm{N}, 134^{\circ} 37^{\prime} \mathrm{E}\right)$ on 11 April 1999 , collected by T. Shimono. Specimens preserved in $70 \%$ ethanol.

\section{Other material examined}

Eight females and six males, dissected and mounted on slides in polyvinyl lactophenol, deposited in the authors' collection.

Diagnosis: Female antennule 8-segmented; antennary exopod with four setae; P2-P4 exopod segment 3 with three external setae.

Female: Total body length $0.7 \mathrm{~mm}$ (45 individuals), measured from the anterior margin of the rostrum to the posterior margin of the caudal rami. Color reddish. Body subcylindrical (Fig. 1A). Rostrum (Fig. 1B) articulated, triangular, apex rounded with two sensilla. Cephalothorax slightly shorter than wide. Genital double-somite divided dorsally and laterally by subcuticular rib.
Genital field (Figure 1C) with copulatory pore situated medially, internal seminal receptacles round. Genital double-somite and following two urosomites fringed with fine spinules around dorsal hind margin. Anal somite with small round anal operculum. Caudal ramus (Fig. 1D) shorter than wide; seta I longer than seta II and slightly longer than seta III; seta IV three-fifths as long as seta V; seta VI as long as seta VII; seta VII triarticulate. Egg-sac single.

Antennule (Fig. 1E) short, 8-segmented. Two aesthetascs present, one on segment 4 , the other one on segment 8 . Setal formula of $1: 9: 9: 6+a: 2: 4: 4: 7+a$.

Antenna (Fig. 1F) with small coxa unarmed, basis incompletely fused with first endopod segment forming allobasis. Exopod short, 1-segmented with three long distal setae and a short lateral seta.

Mandibular gnathobase (Fig. 1G) round, with a long seta at the dorsal corner. Basis large, with a inner seta. Endopod 1-segmented with one lateral and four terminal setae. Exopod 1-segmented with a short seta and five long setae.

Maxillule (Fig. 1H), arthrite of praecoxa with four stout spines and three spinulose setae around distal margin and two subapical surface setae. Coxa with four terminal setae. Basis with two setae on distal margin and one strong seta on lateral margin. Endopod bilobed, with three and two setae, respectively. Exopod 1-segmented, with two setae on distal margin and one seta on lateral margin. Epipodite represented by a seta.

Maxilla (Fig. 2A), syncoxa with three endites; proximal, middle and distal endites bearing one, two and two setae, respectively. Allobasis represented by a strong claw. Endopod absent.

Maxilliped (Fig. 2B) pedestal. Syncoxa armed with two setae at inner corner. Basis with a spinulose seta on inner-lateral margin. Endopod 1-segmented, prehensile with two spinulose setae.

P1 (Fig. 2C), coxa large. Intercoxal sclerite semi-oval, wider than long. Basis with stout spine at inner and outer distal corners. Endopod 3-segmented, prehensile; first segment elongated, longer than exopod, armed with a long seta near inner proximal part; second segment small with an outer spinulose seta; third segment short, armed with two serrate claws and an inner spinulose seta. Exopod 3-segmented; first segment with an outer spine; 


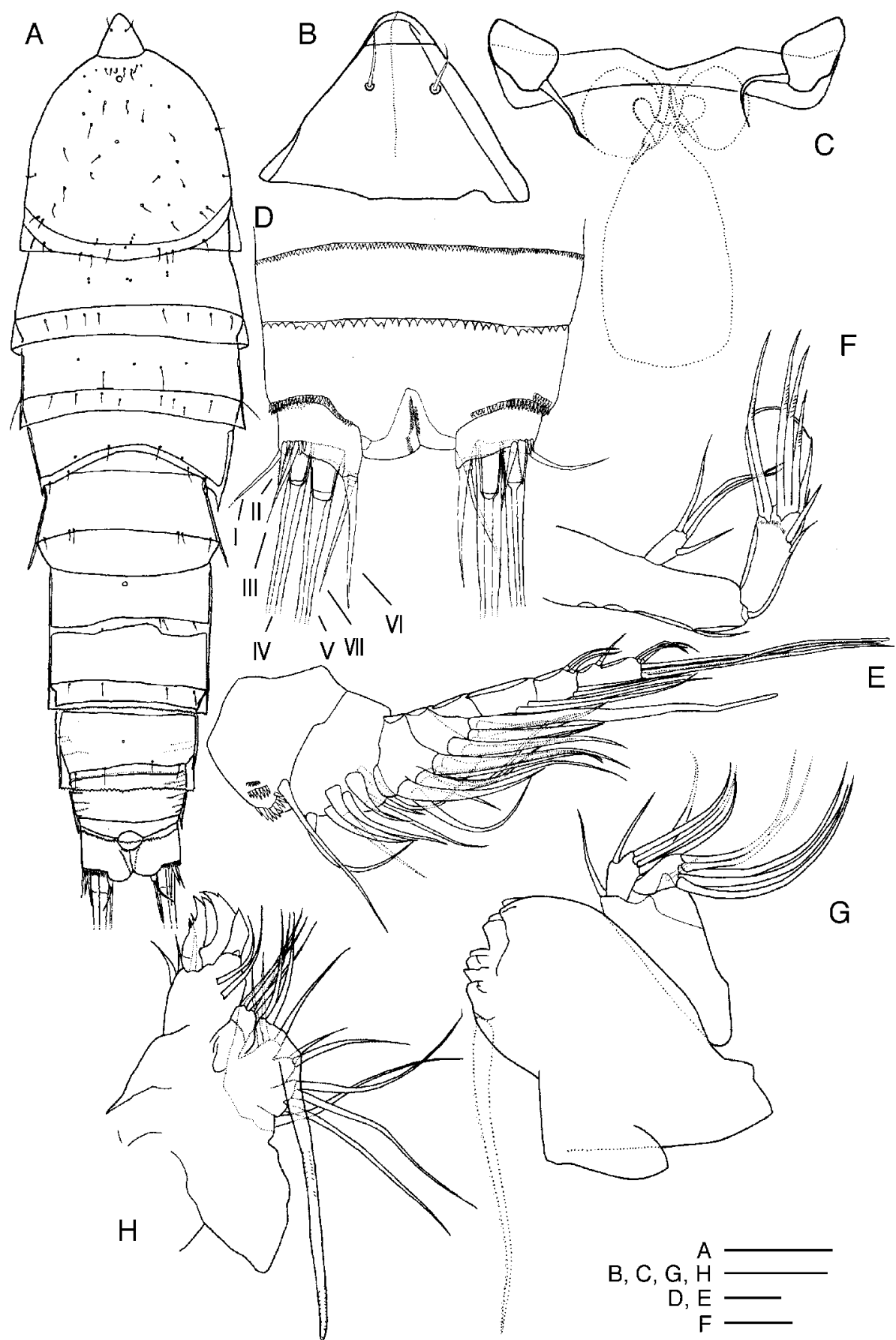

Figure 1. Dactylopusioides fodiens sp. nov., female. (A) whole animal, dorsal view; (B) rostrum, dorsal view; (C) genital field and P.6, ventral view; (D) anal somite and caudal rami, ventral view; (E) antennule; (F) antenna; (G) mandible; (H) maxillule. Scales: A, $0.1 \mathrm{~mm}$; B-H, $0.02 \mathrm{~mm}$. 


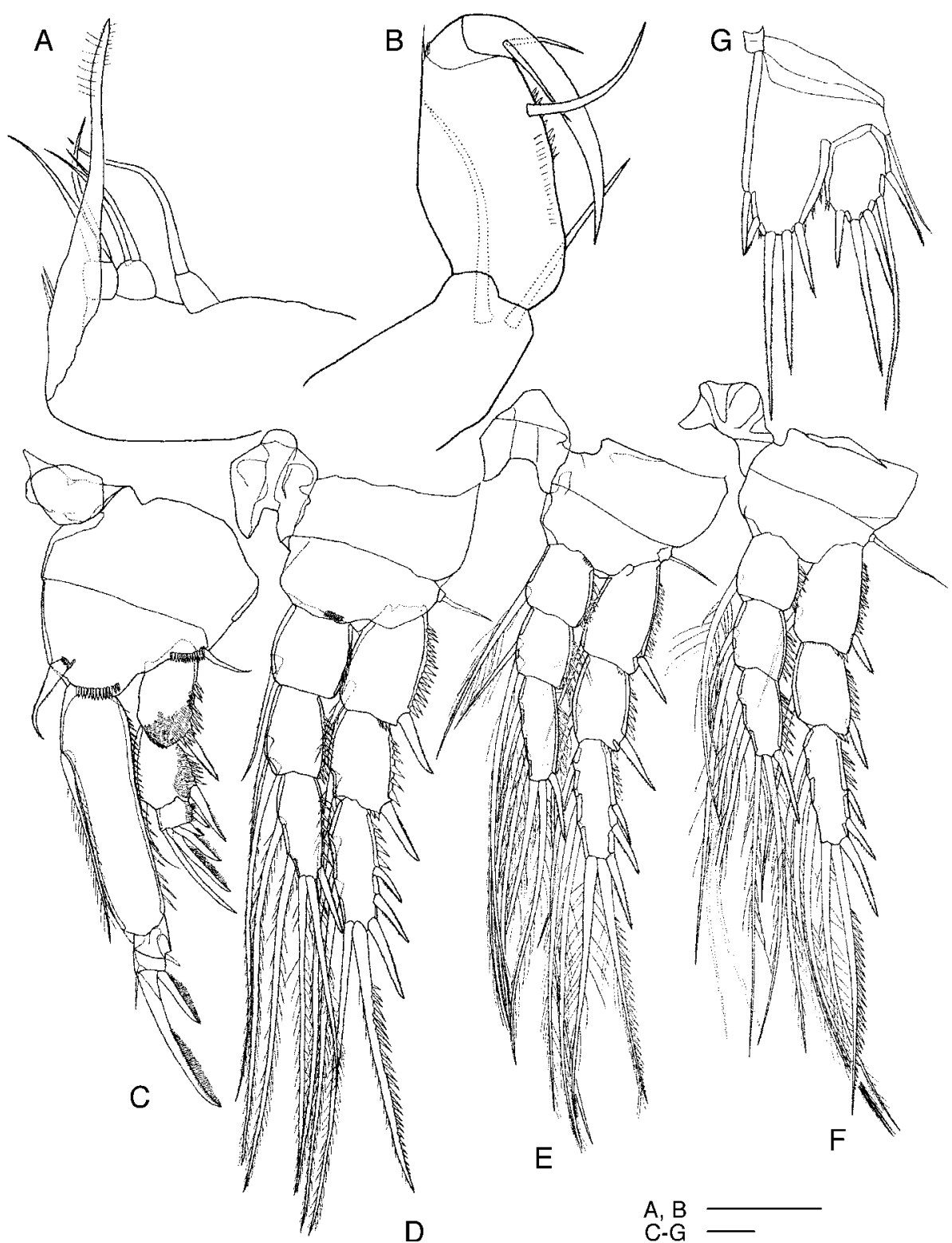

Figure 2. Dactylopusioides fodiens sp. nov., female. (A) maxilla; (B) maxilliped; (C) P.1; (D) P.2; (E) P.3; (F) P.4; (G) P.5. Scales: $0.02 \mathrm{~mm}$.

second segment bearing an outer spine and an inner seta distally; third segment shortest, bearing a spine on outer-lateral edge and four terminal spines that increase in length towards medial edge.

P2-P4 (Figs. 2D-F) coxa rectangular. Intercoxal sclerite longer than wide. Basis with an outer seta. Rami 3-segmented, copiously spinulose, segments of endopod smaller than those of exopod. Setal formula as follows:

\begin{tabular}{lll}
\hline & Exopod & Endopod \\
\hline P2 & $1: 1: 2.2 .3$ & $1: 2: 2.2 .1$ \\
P3 & $1: 1: 3.2 .3$ & $1: 2: 3.2 .1$ \\
P4 & $1: 1: 3.2 .3$ & $1: 2: 2.2 .1$ \\
\hline
\end{tabular}

P5 (Fig. 2G), baseoendopod with five inner setae on endopodal lobe and a naked seta at outer corner, 


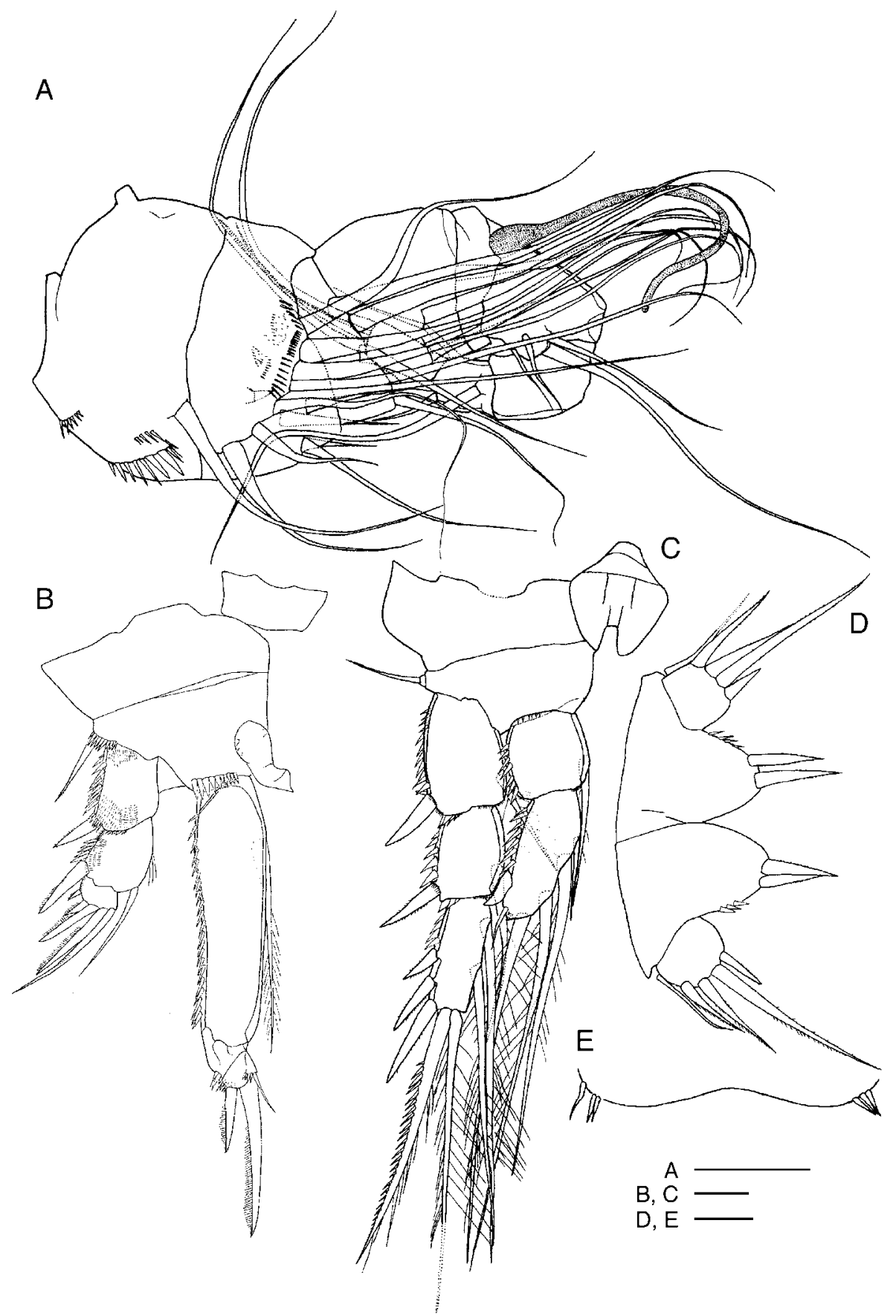

Figure 3. Dactylopusioides fodiens sp. nov., male. (A) antennule; (B) P.1; (C) P.2; (D) P.5; (E) P.6. Scales: 0.02 mm.

endopodal lobe exceeding exopod slightly. Exopod bearing five setae. Minute intercoxal sclerite present.

P6 (Fig. 1C) trapezoidal, bearing an inner seta.

Male: Total length $0.6 \mathrm{~mm}$ (19 individuals). Differs from the female in the following respects.
Antennule (Fig. 3A) clasped, 9-segmented, an aesthetasc present on segment 5 and also on segment 9 .

P1 (Fig. 3B), intercoxal sclerite not oval, long sideways. Inner spine on basis much stouter than that of female. 
P2 (Fig. 3C) endopod modified, 2-segmented; outer spine on second segment shorter and stouter than that of female; outer terminal spine on second segment much smaller than that of female. Setal formula as follows:

\begin{tabular}{lll}
\hline & Exopod & Endopod \\
\hline P2 & $1: 1: 2.2 .3$ & $1: 2.2 .1$ \\
\hline
\end{tabular}

P5 (Fig. 3D), right and left baseoendopods fused medially, bearing two serrate spiniform setae on endopodal lobe and a naked seta at outer corner. Exopod bearing four spinulose setae.

P6 (Fig. 3E) reduced to a small plate with three setae.

Type locality: Imagoura, Hyogo Prefecture, Japan $\left(35^{\circ} 40^{\prime} \mathrm{N}, 134^{\circ} 37^{\prime} \mathrm{E}\right)$.

Ecology: The present species inhabits galleries in the thalli of the brown alga, Dictyota dichotoma. It does not cause any galls on the thallus. It also found in the thalli of brown alga, Pachydictyon coriaceum (Dictyotaceae, Dictyotales) at Imagoura. However, it was not found in other species of related algal taxa (e.g. Dictyopteris prolifera, Dilophus okamurae, Zonaria diesingiana, and Padina arborescens). It was found from April to September in the intertidal and subtidal zones at Imagoura.

Under the laboratory conditions, it fed on $D$. dichotoma and $P$. coriaceum making galleries beneath the cuticle of cortical cells and leaving the epidermal layers uneaten of the seaweed throughout its life. It moved to new galleries every several days. Under $18{ }^{\circ} \mathrm{C}$, a first naupliar stage became adult within 20-30 days. An adult female carried one egg-sac with 6 to 14 eggs and held it for 2-4 days. Then, the egg-sac was laid down in the gallery until the hatching within a few days.

Etymology: The species name refers to the Latin verb fodio $=$ to dig.

\section{Discussion}

The present species has the following unique combination of characters.

1. The antennary exopod is 1-segmented.

2. The first segment of P1 endopod in female is elongated with a long seta on inner proximal margin.
3. The second segment of P2-P4 endopods in female bears two inner setae.

4. The baseoendopod and exopod of P5 in female have five setae respectively.

5. The endopod of P2 in male is 2-segmented.

These characters agree with a diagnosis of Dactylopusioides described by Lang (1948). It concluded that the present species belongs to the genus Dactylopusioides.

Dactylopusioides was represented by a single species, D. macrolabris. The new species, D. foidens differs from $D$. macrolabris in the following characters.

1. The antennule in female of D. macrolabris is 7-segmented; D. fodiens has the 8-segmented antennule.

2. The exopod of antenna in D. macrolabris is armed with three setae; $D$. fodiens has four setae.

3. The number of outer setae on the third segment of P2-P4 exopods in D. macrolabris is two; D. fodiens has three outer setae.

Furthermore, these species are distributed separately as follows: D. macrolabris is distributed in the Mediterranean littoral (Lang, 1948) and Torquay, England on the coast of the English Cannel (Green, 1958); D. fodiens is found in Japan. Additionally, D. macrolabris not only infests Dictyota dichotoma in the same manner as $D$. fodiens but it is also known to infest calcareous algae (Brian, 1928).

\section{Acknowledgements}

We thank Dr Vernon A. Harris of the Australian National University for critical reading of the first draft and Ms. Keiko Ishikawa for translating an Italian paper into Japanese.

\section{References}

Bocquet, C., 1953. Sur un Copépode Harpacticoide mineur, Diarthrodes feldmanni, n. sp. Bulletin de la Societe Zoologique de France 78: 101-105.

Brady, G. S., 1894. On Fucitrogus rhodymeniae, a gall-producing copepod. Journal of the Royal Microscopical Society 1894: 168-170.

Brian, A., 1928. I copepodi bentonici marini. Archivio Zoologico Italiano 12: 294-343.

Fahrenbach, W. H., 1954. A new species of the genus Diarthrodes (Crustacea, Copepoda) parasitic in a red alga. Journal of the Washington Academy of Sciences 44: 326329. 
Fahrenbach, W. H., 1962. The biology of a harpacticoid copepod. La Cellule 62: 303-376.

Green, J., 1958. Dactylopusioides macrolabris (Claus) (Copepoda: Harpacticoida) and its frond mining nauplius. Proceedings of the Zoological Society of London 131: 4954.

Harding, J. P., 1954. The copepod Thalestris rhodymeniae (Brady) and its nauplius, parasitic in the seaweed Rhodymenia palmata (L.) Grev. Proceedings of the Zoological Society of London 124: 153-161.

Hicks, G. R. F., 1977. Species composition and zoogeography of marine phytal harpacticoid copepods from Cook Strait, and their contribution to total phytal meiofauna. New Zealand Journal of Marine and Freshwater Research 11: 441-469.
Ho, J.-S. \& J.-S. Hong, 1988. Harpacticoid copepods (Thalestridae) infesting the cultivated Wakame (brown alga, Undaria pinnatifida) in Korea. Journal of Natural History 22: 1623-1637.

Huys, R., J. M. Gee, C. G. Moore \& R. Hamond, 1996. In Kermack, D. M., R. S. K. Barnes \& J. H. Crothers (eds), Marine and brackish water harpacticoid copepods, Part 1. Synopses of the British fauna (new series) No. 51. The Linnean Society of London and The Estuarine and Coastal Sciences Association, London, $352 \mathrm{pp}$.

Lang, K., 1948. Monographie der Harpacticiden. Håkan Ohlssons Boktryckeri, Lund, 1689 pp.

Tatewaki, M., 1966. Formation of a crustaceous sporophyte with unilocular sporangia in Scytosiphon lomentaria. Phycologia 6: 62-66. 